\title{
KARAKTERISTIK SEKUEN CDNA PENGKODE GEN ANTI VIRUS DARI UDANG WINDU, Penaeus monodon
}

\author{
Andi Parenrengi"), Alimuddin ${ }^{* *}$, Sukenda*n, Komar Sumantadinata**), dan \\ Andi Tenriulo") \\ *) Balai Riset Perikanan Budidaya Air Payau \\ Jl. Makmur Dg. Sitakka, Maros, Sulawesi Selatan 90511 \\ E-mail: andi_parenrengi@hotmail.com \\ **) Departemen Budidaya Perairan-FPIK, Institut Pertanian Bogor \\ Jl. Lingkar Kampus, Kampus IPB Darmaga, Bogor 16680
}

Naskah diterima: 3 Januari 2009; Diterima publikasi: 1 April 2009

\begin{abstract}
ABSTRAK
Transgenesis pada ikan merupakan sebuah teknik modern yang berpotensi besar dalam menghasilkan organisme yang memiliki karakter lebih baik melalui rekombinan DNA gen target termasuk gen anti virus dalam peningkatan resistensi pada udang. Gen anti virus PmAV (Penaeus monodon Anti Viral gene) merupakan salah satu gen pengkode anti virus yang berasal dari spesies krustase. Penelitian ini dilakukan untuk mengetahui karakteristik gen anti virus yang diisolasi dari udang windu, Penaeus monodon. Isolasi gen anti virus menggunakan metode Polymerase Chain Reaction (PCR) dan selanjutnya dipurifikasi untuk sekuensing. Data yang dihasilkan dianalisis dengan program Genetyx Versi 7 dan basic local alignment search tool (BLAST). Hasil penelitian menunjukkan bahwa gen anti virus PmAV yang berhasil diisolasi dari cDNA udang windu dengan panjang sekuen 520 bp yang mengkodekan 170 asam amino. BLAST-N menunjukkan tingkat similaritas yang sangat tinggi (100\%) dengan gen anti virus yang ada di GeneBank. Komposisi asam amino penyusun gen anti virus yang paling besar adalah serin $(10,00 \%)$, sedangkan yang terkecil adalah asam amino prolin dan lisin masing-masing 1,76\%. Analisis sekuen gen dan deduksi asam amino (BLASTP) memperlihatkan adanya C-type lectin-like domain (CTLD) yang memiliki kemiripan dengan gen C-type lectin yang diisolasi dari beberapa spesies krustase.
\end{abstract}

KATA KUNCI: karakteristik, sekuen DNA, detuksi asam amino, gen anti virus, udang windu

ABSTRACT: Characteristics of CDNA sequence encoding anti viral gene from tiger prawn, Penaeus monodon. By: Andi Parenrengi, Alimuddin, Sukenda, Komar Sumantadinata, and Andi Tenriulo

Transgenic fish technology is a potential modern technique in producing better character organism through DNA recombinant of target genes including anti viral gene for improvement of shrimp immunity. PmAV (Penaeus monodon Anti Viral) gene is one of anti viral genes isolated from crustacean species. The research was conducted to analyze the characteristics anti viral gene isolated from tiger prawn, Penaeus monodon. Anti viral gene was isolated using Polymerase Chain Reaction $(P C R)$ technique and then purified for sequencing. Data obtained were analyzed using Genetyx Version 7 software and basic local alignment search tool (BLAST). The results showed that the PmAV antiviral gene has been isolated from CDNA of tiger prawn at the position of approximately 520 bp consisting of 170 amino acids. BLAST-N showed high similarity (100\%) compared to the other anti viral genes deposited at the 
GeneBank. The highest percentage of amino acid encoding anti viral gene is serine (10.00\%), while the lowest is proline and lysine (1.76\%). Sequence analysis and amino acid deduction (BLAST-P) revealed a C-type lectin-like domain (CTLD) that is similar with the C-type lectin gene isolated from several crustacean species.

\section{KEYWORDS: characteristic, cDNA sequence, amino acid deduction, anti viral gene, tiger prawn}

\section{PENDAHULUAN}

Penggunaan teknik biologi molekuler untuk memproduksi strain udang yang memiliki ketahanan tinggi (resisten) terhadap patogen melalui teknologi transformasi genetik merupakan peluang strategi dalam pengendalian penyakit pada udang (Bachere, 2000). Pada dekade terakhir, resistensi terhadap patogen telah dikembangkan pada beberapa spesies tanaman dan hewan termasuk ikan dan udang. Studi introduksi gen asing ke embrio udang melalui metode transfeksi telah menghasilkan data pendahuluan yang telah memperlihatkan ekspresi sementara (transient expression) oleh gen reporter dengan regulator beberapa promoter heterolog. Kemajuan terbaru dalam teknologi transfer gen memiliki potensi sangat besar untuk pengembangan transgenik udang yang membawa gen resisten penyakit atau peningkatan laju pertumbuhan.

Gen pengontrol hormon pertumbuhan (growth hormone, GH) merupakan gen target yang paling banyak digunakan dalam transgenik ikan. Introduksi gen $\mathrm{GH}$ pada ikan telah berhasil diaplikasikan dalam rangka peningkatan kecepatan pertumbuhan, misalnya pada ikan rainbow trout Oncorhynchus mykiss (Penman et al., 1991), salmon Pasifik Oncorhynchus spp. (Devlin et al., 1995), salmon arctic charr Salvelinus alpinus (Pitkanen et al., 1999), mud loach Misgurnus mizalepis (Nam et al., 2001), ikan zebra Danio rerio (Morales et al., 2001), silver sea bream Sparus sarba (Lu et al., 2002), nila Oreochromis niloticus (Rahman et al. 2001; Kobayashi et al., 2007), coho salmon $O$. kisutch (Devlin et al., 2004), dan salmon Atlantik Salmo salar (Yaskowiak et al., 2006). Sementara itu, introduksi gen AFP (anti-freeze protein) pada ikan koki dapat meningkatkan toleransinya terhadap suhu dingin sampai dengan $0^{\circ} \mathrm{C}$ (Wang et al., 1995 dalam Alimuddin et al., 2003), sedangkan transfer gen GFP (green fluorescent protein), YFP (yellow fluorescent protein) dan RFP (red fluores- cent protein) dapat menghasilkan ikan zebra berwarna-warni yang dapat dilihat pada kondisi cahaya biasa (Gong, 2003).

Penerapan teknologi transgenesis dalam peningkatan resistensi ikan dan udang terhadap serangan penyakit atau patogen merupakan salah satu alternatif pemecahan masalah penyakit pada akuakultur. Injeksi gen pengkode glycoprotein IHNV (infectious hematopoetic necrosis virus) menggunakan promoter CMV (cytomegalovirus) pada salmon, menunjukkan proteksi yang signifikan setelah 8 minggu, dan masih tetap resisten serta menunjukkan antibodi penetral virus pada 12 minggu berikutnya (Traxler et al., 1999 dalam Alimuddin et al., 2003). Transfer gen cecropin dapat meningkatkan daya tahan ikan medaka terhadap Pseudomonas fluorescens dan Vibrio anguillarum (Sarmasik et al., 2002). Upaya peningkatan resistensi udang windu terhadap penyakit telah dilakukan melalui injeksi protein rekombinan GST-PAP (glutathione-Stransferase-Phagocytosis Activating Protein) (Chotigeat et al., 2007).

Transgenik udang yang berhasil dilaporkan adalah masih terbatas pada udang vaname, Litopenaeus vannamei dengan mengintroduksikan gen pengkode anti virus TSV-CP (taura syndrome virus coat protein) dengan menggunakan promoter â-actin udang (pâactP2) (Sun et al., 2005; Lu \& Sun, 2005). Gen pengkode anti virus pada udang windu, $P$. monodon yang diberi nama PmAV telah diidentifikasi oleh Luo et al. (2003) dan gen hemocyanin oleh Zhang et al. (2004). Isolasi dan karakterisasi DNA komplementer (cDNA) pengkode anti virus merupakan langkah awal pada proses transfer gen dalam upaya mendapatkan spesies udang yang memiliki resistensi yang tinggi. Penelitian isolasi dan karakterisasi gen anti virus dari udang windu ini dilakukan dengan tujuan untuk mengetahui tingkat similaritas sekuen dengan gen anti virus yang ada dalam Bank Gen. Selain itu, analisis sekuen nukleotida dan deduksi asam aminonya dilakukan untuk mengkonfirmasi kebenaran gen anti virus yang telah diisolasi. 


\section{BAHAN DAN METODE}

\section{Sampel Udang Windu, Penaeus monodon}

Udang windu, P. monodon (50-70 g) yang lolos dari serangan penyakit virus bintik putih (white spot syndrome virus, WSSV) dikoleksi dari tambak udang di Sulawesi Selatan. Udang tersebut diharapkan memiliki gen pengkode ketahanan penyakit yang umumnya diatur oleh promoter tertentu. Hepatopankreas udang windu diambil secara aseptik sebagai bahan untuk ekstraksi RNA.

\section{Ekstraksi RNA}

Sebanyak 10-25 mg sampel hepatopankreas udang windu dimasukkan dalam tabung mikro $(1,5 \mathrm{~mL})$, kemudian dilarutkan dalam $200 \mu \mathrm{L}$ Isogen dalam wadah yang berisi es. Sampel yang sudah digerus dengan grinder tabung mikro ditambahkan kembali Isogen sampai mencapai $800 \mu \mathrm{L}$, kemudian diinkubasi dalam suhu ruangan selama 5 menit agar sampel dapat terlisis sempurna. Sampel ditambahkan dengan 200 $\mu \mathrm{L}$ kloroform kemudian divorteks dengan kecepatan sedang dan dibiarkan kembali dalam suhu ruangan selama 2-3 menit. Sampel disentrifugasi dengan kecepatan 12.000 rpm selama 10 menit kemudian disimpan pada suhu ruangan selama 5 menit dan supernatan yang terbentuk dipindahkan ke dalam tabung mikro baru yang telah berisi dengan $400 \mu \mathrm{L}$ isopropanol. Sampel dihomogenkan dengan membolak-balikkan tabung mikro secara perlahan kemudian disimpan dalam suhu ruangan selama 5-10 menit. Sampel disentrifugasi kembali pada kecepatan 12.000 rpm pada suhu $4^{\circ} \mathrm{C}$ selama 15 menit. Supernatan dibuang, sedangkan pelet dilarutkan dalam $1 \mathrm{~mL}$ etanol 70\% dingin dan kemudian disentrifugasi pada kecepatan $12.000 \mathrm{rpm}$ pada suhu $4^{\circ} \mathrm{C}$ selama 15 menit. Supernatan dibuang, dan selanjutnya tabung mikro dikering-udarakan. Pelet RNA yang tersisa dilarutkan dengan DEPC sebanyak $50 \mu \mathrm{L}$.

Kemurnian dan kandungan RNA total hasil isolasi dapat diketahui dengan menggunakan alat UV-VIS spektrofotometer pada panjang gelombang 260 dan $280 \mathrm{~nm}$. Kemurnian dihitung berdasarkan perbandingan absorbansi $260 \mathrm{~nm}$ dengan $280 \mathrm{~nm}$, sedangkan konsentrasi DNA dapat dihitung berdasarkan absorbansi $260 \mathrm{~nm}$ (Linacero et al., 1998).

\section{Sintesis cDNA dengan RT-PCR}

Sistesis DNA komplementer (complementary DNA, cDNA) dilakukan dengan menggunakan kit Ready-To-Go You-Pime First Strand Beads (GE Healthcare, USA). Konsentrasi RNA dibuat 3 mikrogram dalam $30 \mu \mathrm{L}$ DEPC, kemudian dihomogenasi menggunakan vorteks dengan kecepatan rendah. Tabung mikro berisi RNA dimasukkan ke dalam inkubator dengan suhu $65^{\circ} \mathrm{C}$ selama 10 menit. Selanjutnya tabung mikro dimasukkan ke dalam es selama 2 menit, kemudian RNA dimasukkan ke dalam tabung first strand reaction mix beads yang telah berisi 2 butir bola putih. Primer oligo dT3 race vect (5'-gta ata cga ata act ata ggg cac gcg tgg tcg acg gcc cgg gct ggt ttt ttt ttt ttt ttt t-'3) dengan konsentrasi $1 \mu \mathrm{g} / 3 \mu \mathrm{L}$ ditambahkan sebanyak $3 \mu \mathrm{L}$ ke dalam reaksi, kemudian dibiarkan selama 1 menit. Tabung mikro diinkubasi pada suhu $37^{\circ} \mathrm{C}$ selama 1 jam, kemudian cDNA ditambahkan air steril SDW sebanyak $50 \mu \mathrm{L}$.

\section{Isolasi Gen Anti Virus}

Isolasi gen target (gen anti virus) dilakukan dengan menggunakan cDNA sebagai templat DNA. Gen PmAV diisolasi dengan menggunakan spesifik primer yang dibuat berdasarkan sekuen yang diakses pada GenBank dengan nomor aksessi AY302750.1 (Luo et al., 2003). Primer yang digunakan adalah ORFPmAV-F 5'-tag tgc atg cat atg ggt cat aca atc cta-3' dan ORFPmAV-R 5'-ctg tct cga gct atg tgt cct gct ttc aca-3', dengan target fragmen sepanjang 513 bp yang mencakup kodon awal dan kodon akhir. Primer tersebut telah dilengkapi dengan situs restriksi (digaris bawahi) masing-masing adalah Sphl dan Xhol. Satu milligram cDNA digunakan sebagai templat untuk PCR pada kit PureTaq RTG-PCR Beads (GE Healthcare, USA), kemudian dicampur dengan masing-masing $1 \mu \mathrm{L}$ primer forward dan reverse kemudian ditambahkan air steril sampai mencapai $25 \mu \mathrm{L}$.

Isolasi gen anti virus dilakukan pada mesin PCR (Applied Biosciences 7200). Proses PCR dijalankan pada suhu pre-denaturasi $94^{\circ} \mathrm{C}$ selama 2 menit; 35 siklus untuk denaturasi $94^{\circ} \mathrm{C}$ selama 30 detik, annealing $60^{\circ} \mathrm{C}$ selama 30 detik, ekstensi $72^{\circ} \mathrm{C}$ selama 45 detik; dan final ekstensi $72^{\circ} \mathrm{C}$ selama 7 menit dan penyimpanan sementara pada $4^{\circ} \mathrm{C}$. Untuk mengetahui keberhasilan isolasi gen target, hasil PCR dieletroforesis pada gel agarosa $1 \%$ 
untuk melihat pita DNA yang terbentuk pada gel.

\section{Purifikasi dan Sekuensing Gen Anti Virus}

Gen anti virus hasil PCR selanjutnya dipurifikasi dengan mengunakan kit purifikasi gel GF-1 Gel DNA Recovery Kit (Vivantis, Malaysia) dengan mengacu pada prosedur standar dari manual kit yang digunakan. Hasil purifikasi selanjutnya dilakukan penderetan (sekuensing) dengan mengacu pada metode dideoxynucleotide chain-termination menggunakan mesin otomatis ABI PRIMS 310.

\section{Analisis Data}

Untuk mengetahui kemiripan gen yang dihasilkan, sekuen nukleotida dan deduksi asam amino gen anti virus disejajarkan (aligment) dengan sekuen anti virus yang telah ada di dalam Bank Gen dengan menggunakan program basic local aligment search tool (BLAST-N untuk sekuen nukleotida dan BALST-P untuk sekuen protein atau asam amino). Sekuen gen anti virus hasil penderetan dianalisis dengan menggunakan program GENETYX Versi 7 untuk mendapatkan similaritas sekuen, deduksi asam amino, dan keberadaan parameter penanda signal anti virus.

\section{HASIL DAN BAHASAN}

Gen anti virus telah berhasil diisolasi dari DNA komplementer (cDNA) hepatopankreas udang windu, P. monodon dengan teknik PCR. Pemisahan fragment pada gel elektroforesis memperlihatkan pita tunggal pada posisi sekitar 520 bp (Gambar 1). Gambar tersebut juga memperlihatkan bahwa dengan pemurnian/purifikasi fragmen melalui ekstraksi langsung dari gel dapat menghilangkan latar belakang (smear) dan dimer primer pada bagian bawah gel agarosa (tidak diperlihatkan dalam Gambar). Fragmen yang telah berhasil dimurnikan tersebut dijadikan sampel bahan untuk keperluan sekuensing.

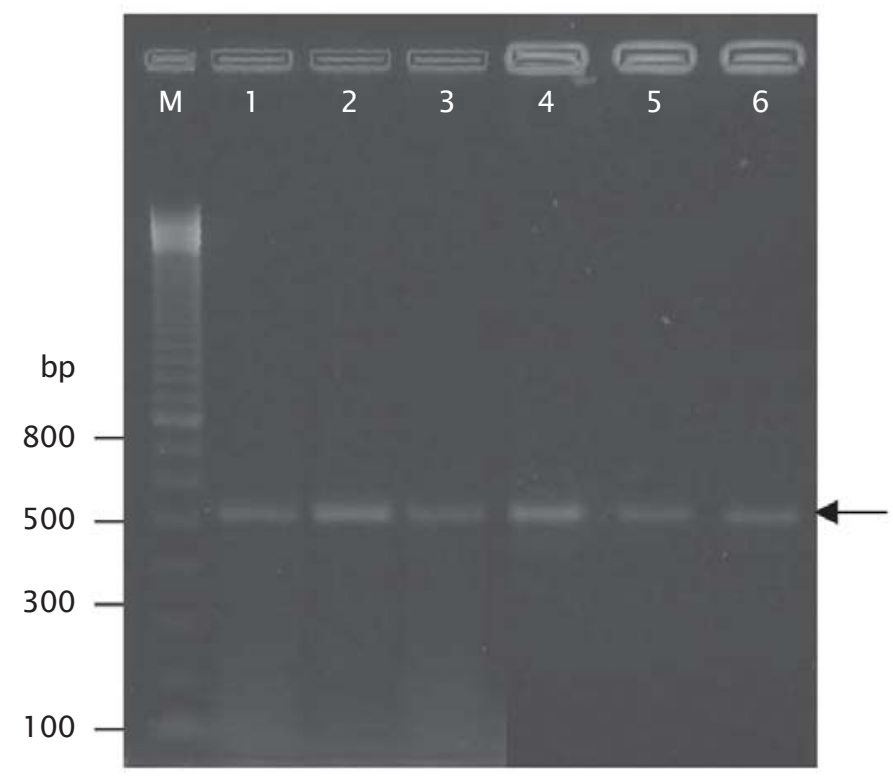

Gambar 1. Fragmen tunggal gen anti virus PmAV yang diisolasi dari DNA komplementer (cDNA) hepatopankreas P. monodon. Tanda panah menunjukkan fragmen gen PmAV pada posisi sekitar 520bp; M=Marker DNA, 1-3=fragmen DNA hasil PCR; dan 4-6=fragmen DNA hasil purifikari dari gel

Figure 1. Single fragment of PmAV anti virus gene isolated from hepatopangcreas CDNA of P. monodon. Arrow indicating the fragment of PmAV gene located at approximately 520bp in length; $M=D N A$ marker, 1-3=DNA fragment of $P C R$ product; and 4-6=DNA fragment of gel purification 
Tabel 1. Similaritas sekuen gen anti virus PmAV yang diisolasi dari udang windu dengan gen anti virus yang terdapat dalam GeneBank

Table 1. Similarity index of PmAV anti viral gene sequence isolated from tiger prawn compared to the anti viral gene accessed at GeneBank

\begin{tabular}{lcccc}
\hline \multicolumn{1}{c}{$\begin{array}{c}\text { Deskripsi } \\
\text { Description }\end{array}$} & $\begin{array}{c}\text { Skor } \\
\text { maksimum } \\
\text { Maximum } \\
\text { score }\end{array}$ & $\begin{array}{c}\text { Jumlah } \\
\text { skor } \\
\text { Total } \\
\text { score }\end{array}$ & $\begin{array}{c}\text { Pemenuhan } \\
\text { query } \\
\text { Query } \\
\text { coverage }\end{array}$ & $\begin{array}{c}\text { Similaritas } \\
\text { Max. } \\
\text { identity }\end{array}$ \\
\hline $\begin{array}{l}\text { mRNA Pm AV P.monodon } \\
\text { (AY302750.1) }\end{array}$ & 942 & 942 & $100 \%$ & $100 \%$ \\
$\begin{array}{l}\text { Gen anti virus P. monodon } \\
\text { (DQ641258.1) }\end{array}$ & 457 & 919 & $96 \%$ & $100 \%$ \\
\hline
\end{tabular}

Analisis BLAST-N terhadap gen anti virus yang didapatkan menunjukkan kemiripan sekuen yang identik (100\%) dengan gen anti virus, baik yang disolasi dari mRNA (AY302750.1) maupun yang berasal dari genom DNA (DQ641258.1) udang windu, P. monodon. Perbedaan query dari kedua gen tersebut adalah $100 \%$ dapat dipenuhinya oleh gen yang diisolasi dari mRNA, sedangkan hanya 96\% pada gen yang diisolasi dari genom DNA (Tabel 1). Hal ini menunjukkan bahwa sekuen gen anti virus udang windu ( $P m A V$ ) yang diisolasi dari mRNA identik dengan sekuen dari gen yang diisolasi pada penelitian ini, tetapi hanya sebagian besar sekuen anti virus dari genom DNA yang dapat disejajarkan yang mungkin disebabkan oleh keberadaan sekuen UTR (untranslated region), intron, dan Poly-A. Hasil pensejajaran tersebut memberikan keyakinan bahwa gen yang telah berhasil diisolasi dari udang windu adalah gen anti virus PmAV.

Tingginya similaritas sekuen nukleotida tersebut memberikan indikator dalam kemiripan deduksi asam amino yang diperoleh setelah translasi melalui program Genetyx. Translasi asam amino diawali dengan sekuen ATG atau dikenal dengan kodon awal yang disandikan oleh asam amino metionin (M). Sedangkan kodon akhir ditandai dengan sekuen TAA yang tidak ditranslasi ke dalam bentuk asam amino, tetapi merupakan sekuen signal berakhirnya aktivitas translasi. Deduksi asam amino dari sekuen gen anti virus yang diisolasi dari udang windu, secara lengkap disajikan pada Gambar 2.

Analisis domain deduksi protein dari cDNA anti virus udang windu menunjukkan adanya situs yang memiliki kemiripan dengan C-type lectin-like domain (CTLD). Susunan CTLD tersebut diperkirakan berada dari urutan asam amino ke-33 sampai dengan ke-166. Hasil pensejajaran asam amino (Gambar 3) menunjukkan bahwa pada urutan ke-33 (sistein) merupakan asam amino pertama yang sama pada gen kelompok C-type lectin pada spesies krustase. CTLD tersebut merupakan salah satu indikator utama dalam prediksi karakter gen fungsional anti virus. Lektin (lectin) adalah merupakan kelompok glikoprotein yang dapat berperan dalam penggumpalan darah (Yatim, 2003), sehingga lektin dikenal juga sebagai salah satu kelompok gen clotting protein (Dong \& Xiang, 2007). Keberadaan CTLD juga telah dilaporkan oleh Luo et al. (2003) pada gen anti virus yang diisolasi dari udang windu dan Kong et al. (2008) pada kepiting Portunus trituberculatus.

Meskipun pada umumnya lectin memperlihatkan aktivitas pengikatan (bind) dalam mendeteksi struktur gula, fungsi mereka pada beberapa organisme berbeda adalah tidak sama. Zelenksky \& Gready (2005) telah mereview dengan lengkap fungsi secara luas dari beberapa famili lectin khususnya $C$-type lectin-like domain. Lectin dikenal memiliki peran penting dalam sistem pertahanan nonspesifik pada invertebrata berdasarkan studi analisis biokimia dari molekuler pada beberapa spesies krustase. Kebanyakan lectin krustase termasuk spesies penaeid, memiliki spesifitas yang umum pada $\mathrm{N}$-acetylated amino sugar khususnya asam sialat (sialic acid) (Marques \& Barracco, 2000). Analisis hambatan hemaglutinasi (hemagglutination inhibition, HAI) lectin kepiting air tawar, Paratelphusa jacquemontii menunjukkan aktivitas sebagai asam sialat spesifik yang memiliki afinitas tinggi pada 0 -acetyl neuraminic acid (Denis 
$\begin{array}{lllll}10 & 20 & 30 & 40 & 50\end{array}$

atgcgtcatacaatcctagtttcctttccctcggtgttgttgggtcggctgtggcaaca $\begin{array}{lllllllllllllllllllll}M & R & H & T & I & L & V & F & L & S & L & G & V & V & G & S & A & V & A & T\end{array}$

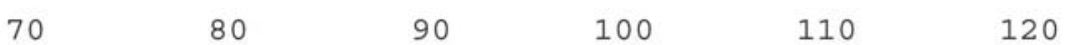

tcatacgagaaaagtgccaatgattccaaggctgtctgctatagcccctatactgccatt $\begin{array}{llllllllllllllllllllll}S & Y & E & K & S & A & N & D & S & K & A & V & C & Y & S & P & Y & T & A & I\end{array}$

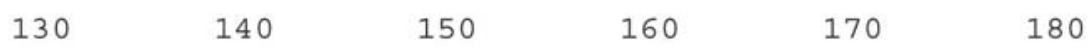

gcggatcgctgtttgtttgtcgatcaccagacagatggaagctggtatgacatgcgagag $\begin{array}{llllllllllllllllllll}A & D & R & C & \text { L } & F & \text { V } & \text { D } & \text { H } & Q & \text { T } & \text { D } & G & \text { S } & \text { W } & Y & \text { D } & M & R & E\end{array}$

$190200 \quad 210 \quad 220 \quad 230 \quad 240$

tactgtaaccttataaatggagactttctcaagctggatgacgctaatctccttactgat $\begin{array}{llllllllllllllllllll}\mathbf{Y} & \mathrm{C} & \mathrm{N} & \mathrm{L} & \mathrm{I} & \mathrm{N} & \mathrm{G} & \mathrm{D} & \mathrm{F} & \mathrm{L} & \mathrm{K} & \mathrm{L} & \mathrm{D} & \mathrm{D} & \mathrm{A} & \mathrm{N} & \mathrm{L} & \mathrm{L} & \mathrm{T} & \mathrm{D}\end{array}$

$250 \quad 260 \quad 270 \quad 280 \quad 290 \quad 300$ atcgttgagtacattacttaccaagtgggtgtgaacagagactactggatcggggggagt $\begin{array}{llllllllllllllllllll}I & V & E & Y & I & T & Y & \& & V & G & \text { V } & \text { N } & \text { R } & \text { D } & \text { Y } & \text { W } & \text { I } & G & G & S\end{array}$

$\begin{array}{lllll}310 & 320 & 330 & 340 & 350\end{array}$

gacgagaaccacgagggtctttggctgtggacggacggaactctcatgcggacaggtgtt $\begin{array}{lllllllllllllllllllll}\text { D } & \text { E } & \text { N } & \text { H } & \text { E } & G & \text { L } & \text { W } & \text { L } & \text { W } & \text { T } & \text { D } & \text { G } & \text { T } & \text { L } & \text { M } & \text { R } & \text { T } & \text { G } & \text { V }\end{array}$

$\begin{array}{llllll}370 & 380 & 390 & 400 & 410 & 420\end{array}$

cccttgtggtaccattgcacctccatctctcaacaaccagatggtggctcctcagagaac $\begin{array}{llllllllllllllllllll}P & L & W & Y & H & C & T & S & I & S & Q & Q & P & D & G & G & S & S & E & N\end{array}$

$\begin{array}{llllll}430 & 440 & 450 & 460 & 470 & 480\end{array}$

tgtgccgtcatgcgctgggactcattttaccatatccatgatgtgtcttgctacacttct

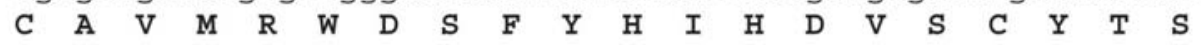

$490 \quad 500 \quad 510$

cggtctgtcatttgtgaaagcaggacacat

$\begin{array}{lllllllllll}R & S & V & I & C & E & S & R & T & H\end{array}$

Gambar 2. Sekuen nukleotida dan hasil deduksi asam amino penyusun gen anti virus PmAV yang diisolasi dari udang windu, P. monodon. Prediksi signal CTLD diindikasikan dengan huruf tebal; huruf kecil simbol nukleotida $a=A d e n i n$, $\mathrm{c}=$ Sitosin, $\mathrm{g}=$ Guanin, $\mathrm{t}=$ Timin; dan deduksi asam amino (huruf kapital) $\mathrm{A}=$ =Alanin, $\mathrm{R}=$ Arginin, $\mathrm{N}=$ Asparagin, $\mathrm{D}=$ Asam aspartat, $\mathrm{C}=$ Sistein, $\mathrm{G}=\mathrm{Glisin}, \mathrm{E}=\mathrm{Asam}$ glutamate, $\mathrm{Q}=$ Glutamin, $\mathrm{H}=$ Histidin, I=Isoleusin, $\mathrm{L}=$ Leusin, $\mathrm{K}=\mathrm{Lisin}, \mathrm{M}=$ Metionin, $\mathrm{F}=$ Fenilalanin, $\mathrm{P}=$ Prolin, $\mathrm{S}=$ Serin, $\mathrm{T}=$ Treonin, $\mathrm{W}=$ Triptofan, $\mathrm{Y}=$ Tirosin, dan $\mathrm{V}=$ Valin

Figure 2. Nucleotide sequence and amino acid deduction of PmAV anti viral gene isolated from tiger prawn, P. monodon. Predicted CTLD is shown in bold letters; nucleotide symbol (small letters) a=Adenine, c=Cytosine, g=Guanine, $t=$ Thymine; and amino acid deduction (capital letters) $A=$ Alanine, $R=$ Arginine, $N=$ Asparagine, $D=$ Aspartic acid; $C=C y$ steine, $G=$ Glysine, E=Glutamic acid, $Q=$ Glutamine, $H=$ Histidine, I=Isoleucine, $L=L$ Lucine, $K=$ Lysine, $M=$ Methionine, $F=$ Phenylalanine, $P=$ Proline, $S=$ Serine, $T=$ Threonine, $W=$ Tryptopan; $Y=$ Tyrosine, and $V=$ Valine 


\begin{tabular}{|c|c|}
\hline & \\
\hline 589 & \\
\hline $\mathrm{ACC} 86854$ & \\
\hline ABI97374 & 190 \\
\hline$\overline{\mathrm{ABI} 97374}$ & 48 \\
\hline$\overline{\mathrm{ABI}} 97372$ & 200 \\
\hline ABI97372 & 55 \\
\hline ACJ0 6428 & 178 \\
\hline ACJ06428 & 36 \\
\hline ABI97373 & 180 \\
\hline ABI97373 & 36 \\
\hline BA54612 & \\
\hline CJ06429 & 36 \\
\hline ACJ06429 & 199 \\
\hline ABU62825 & \\
\hline
\end{tabular}

SAMPEL

AAQ75589

ACC 86854

ABI97374

ABI97374

ABI97372

ABI97372

ACJ06428

ACJ06428

ABI97373

ABI 97373

ABA54612

ACJ06429

ACJ06429

ABU62825

SAMPEL

AAQ75589

ACC 86854

ABI97374

ABI 97374

ABI 97372

ABI97372

ACJ06428

ACJ06428

ABI97373

ABI 97373

ABA54612

ACJ06429

ACJ06429

ABU62825

SAMPEL

A.AQ75589

ACC 86854

ABI 97374

ABI 97374

ABI97372

ABI 97372

ACJ06428

ACJ06428

ABI97373

ABI 97373

ABA54612

ACJ06429

ACJ06429

ABU62825
MRHTILVFLSLGVVGSAVATSYEKSANDSKAVCYSPYTAIAD-RCLFVDHQTDGSWYDMR U. L. . VGILAV. . ATNI.P. .TK--..H. F.E.SG- . VHI.VSKT.T.QN. . . ALAPFGP . VGGRVS. PVLFIE. GG-L. MFVTWAEET.E. A. . PGG. SLVG. $-\mathrm{K}$. . LFVTFVAEPYGEA. ..ALAPFGP . VS.RVT.PILFVEVGG-L.MMFVTWEEET.E.A. A. PGG.SLVGA $-K$. PMFVTFIAQPYSEA.

AA . . ALAPLGP . . VGGRVE. LA. FVEVGG-L . . LFVTWFEDT . ENAQ PGG. . LVGT-K. .MFEIFASETHEEAK . ALVPFGP. .VGGRVT . PDLFVEVGG-L.MAFVTWAEVT.E. AG . PGG . . LVGT-K. .MFEIFASETHEEA. MK. .APVILTTLISVA--A. . SVRATE.P. . . EPLDET . . I.L.AFVSYT. QETV . PEG. SLVGS-Q . MFVTFALENHREAK . PTF . VEVGG-L . . MFVTWAVET . HEAQ

MK. .APVILTALISVASVR. - ...... . PY . .EPLD.T.RI.L.AYVTYT.Q.TV
59

59

54

233

74

243 
Gambar 3. Penyejajaran deduksi asam amino gen anti virus yang diisolasi dari udang windu, $P$. monodon dengan asam amino yang ada dalam Bank Gen (Sampel=gen anti virus yang diisolasi dalam penelitian ini; AAQ75589=PmAV Penaeus monodon; ACC86854=C-type lectin-like domain-containing protein PtLP Portunus trituberculatus; ABI97374= Ctype lectin C-type lectin Litopenaeus vannamei; ABI97372= C-type lectin Penaeus semisulcatus; ACJ06428= C-type lectin 5 Fenneropenaeus chinensis; ABI97373= Ctype lectin Penaeus monodon; ABA54612= C-type lectin F. chinensis; ACJ06429=Ctype lectin 4 F. chinensis; dan ABU62825= C-type lectin L. vannamei

Figure 3. Alignment of amino acid deduction of anti viral gene isolated from tiger prawn, $\boldsymbol{P}$. monodon compared to the other genes at the GenBank. (Sample=anti viral gen isolated from tiger prawn on this research; AAQ75589=PmAV P. monodon; ACC 86854=C-type lectin-like domain-containing protein PtLP Portunus trituberculatus; AB197374= C-type lectin C-type lectin Litopenaeus vannamei; AB197372= C-type lectin Penaeus semisulcatus; ACJ06428=C-type lectin 5 Fenneropenaeus chinensis; $A B 197373=C$-type lectin P. monodon; $A B A 54612=C$ type lectin F. chinensis; ACJ06429= C-type lectin 4 F. chinensis; and ABU62825=Ctype lectin L. vannamei

et al., 2003). Sedangkan studi yang dilakukan oleh Ma et al. (2007) memperlihatkan indikasi peranan penting molekul lectin pada mekanisme pertahanan inang dekapoda dalam pembersihan infeksi patogen. Studi yang dilakukan oleh Sun et al. (2007) mengindikasikan bahwa lectin vaname $L$. vannamei memperlihatkan hambatan yang luas pada lipo-polisakarida bakteri gram negatif yang mengindikasikan peranan signifikan secara in vivo pada agglutinin humoral dalam respon inang melawan infeksi bakteri.

Pada studi lainnya, kloning gen lectin pada level molekuler dan karakteriasi C-type lectin telah dilaporkan, misalnya pada udang windu, $P$. monodon yang dikenal dengan anti virus lectin-like protein dengan carbohydraterecognition domain (CRDs) (Luo et al., 2003) dan lectin yang memiliki kemampuan

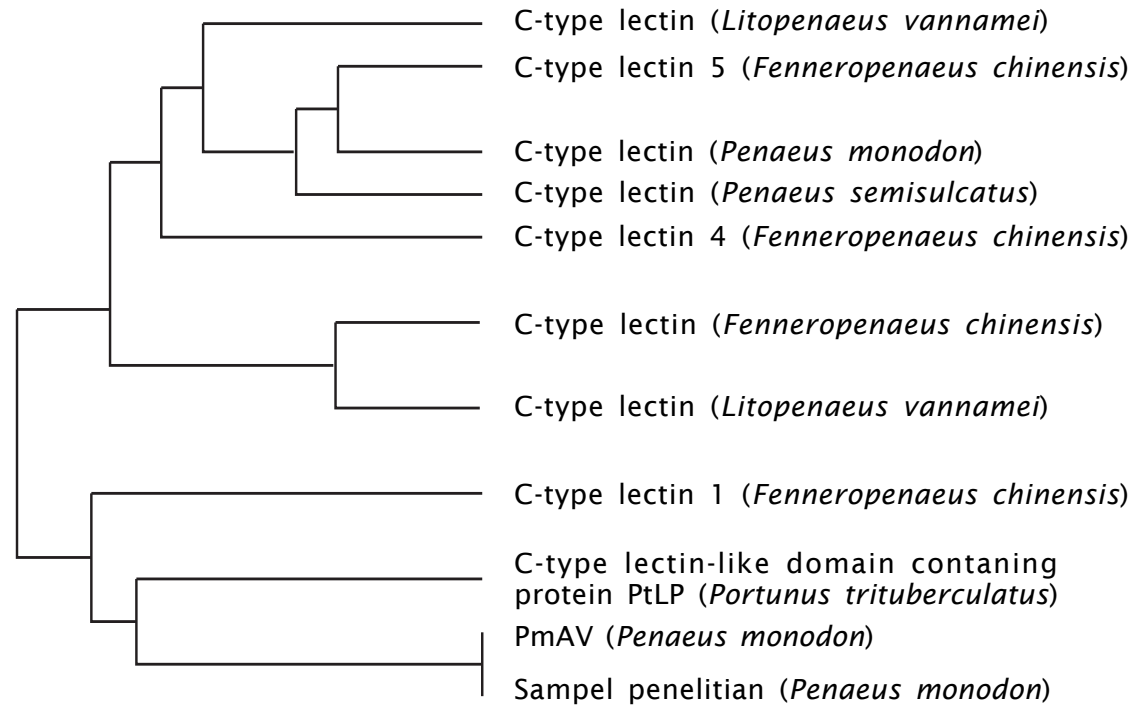

Gambar 4. Filogenetik gen anti virus yang diisolasi dari udang windu, P. monodon berdasarkan deduksi asam amino cDNA

Figure 4. Phylogenetic of anti viral gen isolated from tiger prawn, P. monodon based on the amino acid deduction of CDNA 
pengikatan lipo-polisakarida (Zhang et al., 2004). Selanjutnya Luo et al. (2006), melaporkan bahwa lectin dari cDNA udang $P$. monodon (PmLec) berperan dalam imunitas non-spesifik khususnya dalam fungsinya sebagai pengenal protein dan opsonin. Zhao et al. (2009) juga melaporkan bahwa C-type lectin khususnya C-type lectin 1 dari $L$. vannamei (LvCTL1) memperlihatkan aktivitas yang sangat tinggi melawan WSSV melalui interaksi beberapa protein WSSV.

Gambar filogenetik (Gambar 4) menunjukkan bahwa gen anti virus yang ditemukan memiliki deduksi asam amino yang identik dengan gen anti virus PmAV dengan nomor aksesi AAQ75589.1 pada Bank Gen. Keberadaan CTLD pada gen yang diisolasi juga didukung dengan kemiripan gen pengkode CTLD yang telah diisolasi dari kepiting, Portunus trituberculatus yang dikenal sebagai C-type lectin-like domain-containing protein PtLP dengan nomor akses ACC86854.1. Selain itu, Gambar 4 memperlihatkan kekerabatan beberapa gen yang mengkodekan C-type lectin yang diisolasi dari beberapa spesies krustase misalnya dari L. vannamei (nomor aksesi AB197374.1; ABU62825.1), P. semisulcatus (nomor aksesi ABI97372.1), F. chinensis (ACJ06428.1; ABA54612.1; ACJ06429.1), P. monodon (nomor aksesi ABI97373.1; AAZ29608.1).

Gen anti virus yang diisolasi dari udang windu ini tersusun atas 170 asam amino yang dideduksi dari sekuen cDNA. Komposisi asam amino penyusun gen anti virus yang terbesar adalah serin $(10,00 \%)$, sedangkan yang terkecil adalah asam amino prolin dan lisin masingmasing 1,76\%. Komposisi deduksi terhadap 20 jenis asam amino dari sekuen cDNA anti virus dari udang windu disajikan pada Gambar 5 . Deduksi asam amino yang didapatkan pada gen anti virus tersebut lebih besar dibandingkan dengan beberapa deduksi asam amino dari gen antimikroba yang ditemukan sebelumnya, misalnya gen PAP (phagocytosis activating protein) terdiri atas 546 bp yang mengkode 144 asam amino (Chotigeat et al., 2007), antimikroba peptida krustase (penaeidin, P3-a) tersusun atas 82 asam amino (Destoumieux et al., 1997).

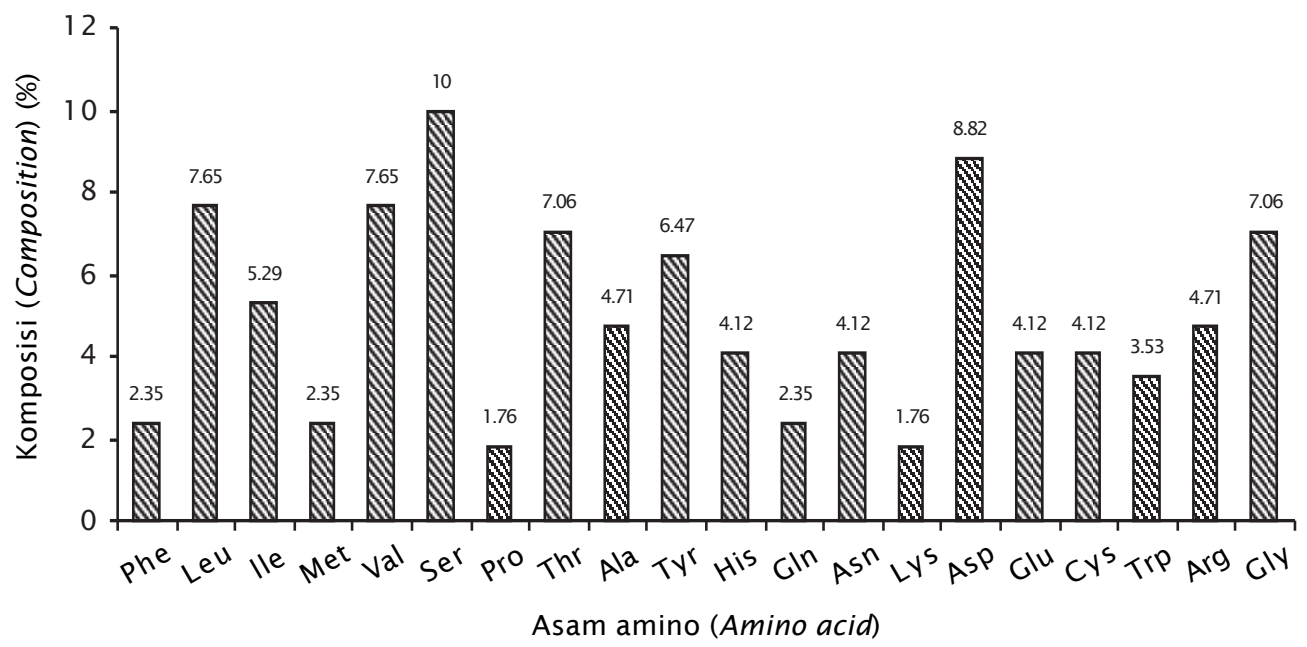

Gambar 5. Komposisi asam amino yang terdapat pada gen anti virus yang diisolasi dari udang windu, $P$. monodon (Phe=Fenilalanin, Leu=Leusin, $\mid l e=I$ soleusin, Met=Metionin, Val=Valin, Ser=Serin, Pro=Prolin, Thr=Treonin, Ala=Alanin, Tyr=Tirosin, His=Histidin, $\mathrm{Gln}=$ Glutamin, Asn=Asparagin, Lys=Lisin, Asp=Asam aspartat, $\mathrm{Glu}=$ Asam glutamat, Cys=Sistein, Trp=Triptofan, Arg=Arginin, dan Gly=Glisin)

Figure 5. Composition of amino acid in antiviral gene isolated from tiger prawn, P. monodon (Phe=Phenylalanine, Leu=Leucine, Ile=Isoleucine, Met=Methionine, Val=Valine, Ser=Serine, Pro=Proline, Thr=Threonine, Ala=Alanine, Tyr=Tyrosine, His=Histidine, Gln=Glutamine, Asn=Aspartic acid, Lys=Lysine, Asp=Asparagine, Glu=Glutamic acid, Cys=Cysteine, Trp=Tryptopan, Arg=Arginine, and Gly=Glysine) 
Komposisi yang sama juga telah dilaporkan pada deduksi asam amino dari sekuen cDNA PmAV yang diisolasi dari udang windu (Luo et al., 2003). Hal yang relatif berbeda, didapatkan pada deduksi asam amino pada gen $\mathrm{GH}$ pada umumnya. Syaifudin (2006) menemukan bahwa gen GH dari cDNA ikan kerapu bebek tersusun atas 205 asam amino dimana komposisi terbesar adalah asam amino leusin $(14,63 \%)$ dan serin $(12,20 \%)$ dan terkecil adalah triptofan $(0,49 \%)$. Berbeda halnya dengan gen antimikroba penaeidin dimana deduksi asam aminonya memperlihatkan persentase asam amino prolin sangat tinggi (22\%-29\%) pada daerah hulu dan asam amino sistein (19\%-23\%) pada daerah hilir (Destoumieux et al., 1997; 2000).

Isolasi dan identifikasi gen pengkode ketahan penyakit merupakan langkah awal yang dilakukan dalam upaya peningkatan imunitas pada udang. Dong \& Xiang (2007) telah menemukan sedikitnya 34 gen yang dilibatkan dalam fungsi pertahanan/imunitas pada haemocyte pustaka cDNA dari udang F. chinensis, dimana $38 \%$ di antaranya teridentifikasi sebagai gen antimikroba peptida (AMP, penaeidin dan antilipopolysaccharida), sedangkan selebihnya adalah gen sistem pro-phenoloksidase (32\%) misalnya proPO, serin proteinase; gen clotting protein (15\%) misalnya lectin, transglutaminase; gen signal transduksi interselular (9\%) misalnya peroxinectin, integrin; dan gen shaperone protein (6\%) misalnya HSP70, thioredoxin peroxidase.

Pendekatan teknologi rekombinan khususnya vaksin DNA telah mulai diaplikasikan pada akuakultur. Penyuntikan salmon Atlantik dengan plasmid pengkode glikoprotein IHNV dengan menggunakan promotor cytomegalovirus (pCMV) menunjukkan proteksi yang signifikan dengan adanya pembentukan antibodi penetral virus setelah imunisasi dan titernya meningkat setelah uji tantang (Traxler et al., 1999 dalam Alimuddin et al., 2003).

Salah satu mekanisme yang potensial dalam peningkatan resistensi penyakit adalah produksi hewan akuatik transgenik yang mengandung gen antimikroba peptida. Beberapa informasi telah tersedia luas terkait dengan antibakteri peptida (Bevins \& Zasloff, 1990; Lehrer et al., 1993; Boman, 1996; Hoffmann et al., 1996; Hancock, 1997) dimana organisme yang mengandung gen pengkodenya memperlihatkan resistensi patogen yang lebih tinggi. Penemuan cecropin (cationic peptide) (Steiner et al., 1981) sebagai antibakteri merupakan awal dari penelitian antimikroba yang selanjutnya diidentifikasinya beberapa antimikroba lainnya. Struktur yang unik dari cecropin dapat menyebabkan penyatuan sampai membran seluler bakteri, jamur, dan parasit sehingga membentuk pori pada membran yang menyebabkan kematian pada patogen (Bechinger, 1997). Studi in vitro mengindikasikan bahwa transgenesis menggunakan konstruksi cecropin dapat meningkatkan resistensi organisme. Introduksi konstruksi lytic peptida cecropin-B meningkatkan resistensi terhadap bakteri sampai dengan empat kali lipat pada channel catfish (Dunham et al., 2002). Hal yang sama juga ditunjukkan pada transgenik ikan medaka yang memiliki resistensi lebih tinggi dibandingkan dengan ikan non-transgenik terhadap bakteri Pseudomonas sp. dan Vibrio sp. (Sarmasik et al., 2002). Gen lysozyme telah dilaporkan merupakan salah satu gen pengkode ketahanan penyakit khususnya antimikroba yang tidak spesifik (Austin \& Allen-Austin, 1985 dalam Alimuddin et al., 2003). Dengan menggunakan konstruksi promoter ocean pout AFP dan gen lysozyme yang diintroduksi ke ikan salmon menunjukkan adanya kemampuan melawan berbagai jenis mikroba (resisten).

Pada krustase, khususnya pada udang, peningkatan resistensi melalui teknologi transgenesis masih terbatas. Chotigeat et al. (2007) juga telah berhasil mengidentifikasi gen PAP yang memiliki aktivitas dalam peningkatan fogositas haemocyte pada udang windu sehingga dengan injeksi intra-muscular dapat meningkatkan resistensi udang windu terhadap WSSV dibandingkan dengan kontrol (tanpa injeksi gen PAP). Penemuan gen pengkode antimikroba penaeidin membuka peluang dalam peningkatan immunitas udang melawan serangan pathogen. Aplikasi penaeidin telah memperlihatkan efek peningkatan resistensi pada udang $L$. vannamei (Destoumieux et al., 1997). Induksi imun pada udang melalui vaksinasi telah dilaporkan dengan penggunaan rekombinan protein WSSV pada udang P. chinensis (Kim et al., 2004), antiviral menggunakan dobel-strand RNA (double-stranded RNA, dsRNA) pada udang L. vannamei (Robalino et al., 2004). 


\section{KESIMPULAN}

Gen anti virus $P m A V$ telah berhasil diisolasi dari cDNA udang windu, $P$. monodon yang memiliki sekuen yang identik (100\%) dengan gen anti virus yang ada pada Bank Gen. Gen anti virus tersebut tersusun atas 170 asam amino, dimana komposisi asam amino penyusun gen tersebut tertinggi adalah serin (10,00\%), sedangkan yang terkecil adalah prolin dan lisin masing-masing 1,76\%. Analisis sekuen memperlihatkan keberadaan C-type lectin-like domain (CTLD) yang merupakan indikator utama suatu gen pengkode anti virus.

\section{UCAPAN TERIMA KASIH}

Penelitian ini dibiayai oleh APBN dari DIPA Balai Riset Perikanan Budidaya Air Payau (BRPBAP) Maros, Tahun Anggaran 2007. Ucapan terima kasih disampaikan kepada kepala dan peneliti/teknisi BRPBAP Maros serta staf Laboratorium Reproduksi dan Genetika Organisme Akuatik, IPB, Bogor yang telah membantu kelancaran pelaksanaan penelitian ini.

\section{DAFTAR ACUAN}

Alimuddin, Yoshizaki, G., Carman, O., \& Sumantadinata, K. 2003. Aplikasi transfer gen dalam akuakultur. Jurnal Akuakultur Indonesia, 2(1): 41-50.

Bachere, E. 2000. Introduction shrimp immunity and diseases control. Aquaculture, 191: 3-11.

Bechinger, B. 1997. Structure and function of channel-forming peptides: magainins, cecropins, melittin and alamethicin. J. Membran Biology, 156: 197-211.

Bevins, C.L. \& Zasloff, M. 1990. Peptides from frog skin. Annu Rev Biochem., 59: 395-414.

Boman, H.G. 1996. Peptide antibiotics: holy or heretic grails of innate immunity. Scandinavian Journal of Immunology, 43: 475-482.

Chotigeat, W., Deachamag, P., \& Phongdara, A. 2007. Identification of a protein the phagocytosis activating protein (PAP) in immunized black tiger shrimp. Aquaculture. 271: 112-120.

Denis, M., Palatty, P.D.M., Bai, N.R., and Suriya, S.J. 2003. Purification and characterization of a sialic acid specific lectin from the hemolymph of the freshwater crab Paratelphusa jacquemontii. Eur. J. Biochem., 270: 4,348-4,355.
Destoumieux, D., Bulet, P., Loew, D., Dorsselaer, Rodriguez, J., \& Bachere, E. 1997. Penaeidins, a new family of antimicrobial peptides isolated from the shrimp Penaeus vannamei (Decapoda). The Journal of Biological Chemistry, 272(45): 28,398-28,406.

Destoumieux, D., Munoz, M., Bulet, P., and Bachere E. 2000. Review: penaeidins, a family of antimicrobial peptides from penaeid shrimp (Crustacea, Decapoda). CMLS Cellular and Molecular Life Science, 57: 1,260-1,271.

Devlin, R.H., Yesaki, T.Y., Donaidson, E.M., Du, S.J., and Hew, C.L. 1995. Production of germline transgenic Pacific salmonids with dramatically increased growth performance. Can J Fish Aquat Sci., 52: 1,3761,384 .

Devlin, R.H., Biagi, C.A., \& Yesaki, T.Y. 2004. Growth, viability and genetic characteristics of $\mathrm{GH}$ transgenic coho salmon strains. Aquaculture. 236: 607-632.

Dong, B. \&, Xiang, J.H. 2007. Discovery of genes involved in defense/immunity functions in a haemocytes cDNA library from Fennaropenaeus chinensis by EST annotation. Aquculture, 272: 208-215.

Dunham, R.A., Warr, G., Nichols, A., Duncan, P.L., Argue, B., Middleton, D., \& Liu, Z. 2002. Enhanced bacterial diseases resistance of transgenic channel catfish, Ictalarus punctatus, possesing cecropin genes. Mar Biotechnol., 4: 338-344.

Gong, Z. 2003. Generation of living color trangenic zebrafish. In Shimizu, N., Aoki, T., Hirono, I., Takashima F (Eds.): Step Toward a Green Future, p. 329-339.

Hancock, R.E.W. 1997. Peptide antibotics. Lancet, 349: 418-422.

Hoffmann, J.A., Reichhart, J.M., \& Hetru, C. 1996. Innate immunity in higher insects. Current Opinion in Immmunology, 8: 8-13.

Kim, D.K., Jang, I.K., Seo, H.C., Shin, S.O., Yang, S.Y., \& Kim, J.W. 2004. Shrimp protected from WSSV disease by treatment with egg yolk antibodies (IgY) against a truncated fusion protein derivated from WSSV. Aquaculture, 237: 21-30.

Kobayashi, S.I., Alimuddin, Morita, T., Miwa, M., Lu, J., Endo, M., Takeuchi, T., Yoshizaki, G. 2007. Transgenic Nile tilapia (Oreochromis niloticus) over-expressing growth hormone showed reduced ammonia excretion. Aquaculture, 270: 427-435. 
Kong, H.J., Park, E.M., Nam, B.H., Kim, Y.O., Kim, W.J., Park, H.J., Lee, C.H., \& Lee, S.J. 2008. A C-type lectin like-domain (CTLD)-containing protein (PtLP) from the swimming crab Portunus trituberculatus [abstract]. Fish Shellfish Immunology, 25(3): 311-314.

Lehrer, R.I., Lichtenstein, A.K., \& Ganz, T. 1993. Defensins: antimicrobial and cytotoxic peptides of mammalian cells. Annu Rev Immunol., 11: 105-128.

Linacero, R.J., Rueda, \& Vazquez, A.M. 1998. Quantification of DNA. In Karp AP, Isaac G, Ingram DS (Editors.) Molecular Tools for Screening Biodiversity: Plants and Animals. Chapman and Hall. London, Weinheim, New York, Tokyo, Melbourne, Madras, p. 18-21.

Lu, J.K., Fu, B.H., Wu, J.L., \& Chen, T.T. 2002. Production of trangenic silver sea bream (Sparus sarba) by different gene transfer methods. Marine Biotechnology, 4: 328337.

Lu, Y. \& Sun, P.S. 2005. Viral resistance in shrimp that express an antisense taura syndrome virus coat protein gene. Antiviral Research, 67: 141-146.

Luo, T., Zhang, X., Shao, Z., \& Xu, X. 2003. PmAV, a novel gene involved in virus resistence of shrimp Penaeus monodon. FEBS Letter, 551: 53-57.

Luo, T., Yang, H., Li, F., Zhang, X., \& Xu Xun. 2006. Puification, characterization and cDNA cloning of a novel lipopolysaccharide-binding lectin from the shrimp Penaeus monodon [abstract]. Development \& Comparative Immunology, 30(7): 607-617.

Ma, T.H.T., Tiu, S.H.K., He, J.G., \& Chan, S.M. 2007. Molecular cloning of a C-type lectin (LVLT) from the shrimp Litopenaeus vannamei: Early gene down-regulation after WSSV infection. Fish \& Shellfish Immunology, 23: 430-437.

Marques, M.R.F. \& Barracco, M.A. 2000. Lectins, as non-self-recognition factors, in crustaceans. Aquaculture, 191: 23-44.

Morales, R., Herrera, M.T., Arenal, A., Cruz, A., Hernandez, O., Pimentel, R., Guillen, I., Martinez, R., \& Estrada, M.P. 2001. Tilapia chromosomal growth hormone gene expression accelerates growth in transgenic zebrafish (Danio rerio). Journal of Biotechnology, 4(2): 52-58.

Nam, Y.K., Noh, J.K., Cho, Y.S., Cho, H.J., Cho, K.N., Kim, C.G., and Kim, D.S. 2001. Dramatically accelerated growth and extraordinary gigantism of transgenic mud louch
Misgurnus mizolepis. Transgenic Research, 10: 353-362.

Penman, D.J., lyengar, A., Beeching, A.J., Rahman, M.A., Sulaiman, Z., and Maclean, N. 1991. Patterns of transgens inheritance in rainbow trout (Oncorhynchus mykiss). Mol Rep Dev., 30: 201-206.

Pitkanen, T.I., Krasnov, A., Teerijoki, H., \& Molsa, H. 1999. Transfer of growth hormone (GH) transgenes into Arctic charr (Salvenus alpinus L.): I. Growth response to various $\mathrm{GH}$ constructs. Genetic Analysis: Biomolecular Engineering. 15: 91-98.

Rahman, M.A., Ronyai, A., Engidaw, B.Z., Jauncey, K., Hwang, G.L., Smith, A., Roderick, E., Penman, D., Varadi, L., \& Maclean, N. 2001. Growth and nutritional trials on transgenic Nile tilapia containing an exogenous fish growth hormone gene. J Fish Biol., 59: 62-78.

Robalino, J., Browdy, C.L., Prior, S., Metz, A., Parnell, P., Gross, P., \& Warr, G. 2004. Induction of antiviral immunity by doublestranded RNA in a marine invertebrata. Journal of Virology, 78(19): 10,442-10,448.

Sarmasik, A., Warr, G., \& Chen, T.T. 2002. Production of transgenic medaka with increased resistance to bacterial pathogen. Mar Biotechnol., 4: 310-322.

Steiner, H., Hultmark, D., Engstrom, A., Bennich, H., \& Boman, H.G. 1981. Sequence and specificity of two antibacterial proteins involved in insect immunity. Nature, 292: 246-248.

Sun, J., Wang, L., Wang, B., Guo, Z., Liu, M., Jiang, K., \& Luo, Z. 2007. Purification and characterisation of a natural lectin from the serum of the shrimp Litopenaeus vannamei. Fish \& Shellfish Immunology, 23: 292-299.

Sun, P.S., Venzon, N.C., Calderon, F.R.O., \& Esaki, D.M. 2005. Evaluation of methods for DNA delivery into shrimp zygotes of Penaeus (Litopenaeus) vannamei. Aquaculture, 243: 19-26.

Syaifudin, M. 2006. Isolasi dan karakterisasi cDNA hormone pertumbuhan ikan kerapu bebek (Cromileptes altivelis). Thesis Sekolah Pasacasarjana, Institut Pertanian Bogor, $63 \mathrm{hlm}$.

Yatim, W. 2003. Kamus Biologi. Yayasan Obor Indonesia, Jakarta, $907 \mathrm{hlm}$.

Yaskowiak, E.S., Shears, M.A., Agarwal-Mawal, A., \& Fletcher, G.L. 2006. Characterization and multi-generational stability of the growth hormone transgene (EO- $1 \alpha$ ) respon- 
sible for enhanced growth rate in Atlantic salmon. Transgenic Research, 15: 465-480.

Zelensky, A.N. \&, Gready, J.E. 2005. The C-type lectin-like domain superfamily. The FEBS Journal, 272: 6,179-6,217.

Zhang, X., Huang, C., \& Qin, Q. 2004. Antiviral properties of haemocyanin isolated from shrimp Penaeus monodon. Antiviral Research, 61: 93-99.
Zhao, Z.Y., Yin, Z.X., Xu, X.P., Weng, S.P., Rao, X.Y., Dai, Z.X., Luo, Y.W., Yang, G., Li, Z.S., Guan, H.J., Li, S.D., Chan, S.M., Yu, X.Q., \& He, J.G. 2009. A novel C-type lectin from the shrimp Litopenaeus vannamei possesses anti-white spot syndrome virus activity [abstract]. Journal of Virology, 38(1): 347-356. 